\title{
Optimizing productivity in oil rims: simulation studies on horizontal well placement under simultaneous oil and gas production
}

\author{
Oluwasanmi Olabode ${ }^{1}\left[\right.$ D $\cdot$ Sunday Isehunwa ${ }^{2} \cdot$ Oyinkepreye Orodu $^{1} \cdot$ Daniel Ake $^{1}$
}

Received: 30 July 2020 / Accepted: 6 October 2020 / Published online: 27 November 2020

(c) The Author(s) 2020

\begin{abstract}
Thin oil rim reservoirs are predominantly those with pay thickness of less than $100 \mathrm{ft}$. Oil production challenges arise due to the nature of the gas cap and aquifer in such reservoirs and well placement with respect to the fluid contacts. Case studies of oil rim reservoir and operational properties from the Niger-Delta region are used to build classic synthetic oil rim models with different reservoir parameters using a design of experiment. The black oil simulation model of the ECLIPSE software is activated with additional reservoir properties and subsequently initialized to estimate initial oil and gas in place. To optimize hydrocarbon production, 2 horizontal wells are initiated, each to concurrently produce oil and gas. Well placements of $(0.5 \mathrm{ft}$., $0.25 \mathrm{ft}$. and $0.75 \mathrm{ft}$.) are made with respect to the pay thickness and then to the fluid contacts. The results show that for oil rim with bigger aquifers, an oil recovery of $8.3 \%$ is expected when horizontal wells are placed at $0.75 \mathrm{ft}$. of the pay thickness away from the gas oil contact, $8.1 \%$ oil recovery in oil rims with larger gas caps with completions at $0.75 \mathrm{ft}$. of the pay zone from the gas oil contacts, $6 \%$ oil recovery with relatively small gas caps and aquifer and $9.3 \%$ from oil rims with large gas caps and aquifers, with completions at mid-stream of the pay zone.
\end{abstract}

Keywords Well placement $\cdot$ Oil recovery $\cdot$ Horizontal well $\cdot$ Reservoir simulation $\cdot$ Concurrent production

$\begin{array}{ll}\text { Abbreviations } \\ \text { WOC } & \text { Water oil contact } \\ \text { GOC } & \text { Gas oil contact } \\ \text { HWL } & \text { Horizontal well length } \\ \text { Krw } & \text { Water relative permeabilty } \\ \text { WOPR } & \text { Well oil production rate } \\ \text { WGPT } & \text { Well gas production total } \\ \text { FOE } & \text { Field oil efficiency } \\ \text { WWCT } & \text { Well water cut } \\ \text { SGFN } & \text { Gas saturation function } \\ \text { GOR } & \text { Gas oil ratio } \\ \text { BHP } & \text { Bottom hole pressure } \\ \text { IOIP } & \text { Initial oil in place } \\ \text { GIIP } & \text { Gas initially in place } \\ \text { PVTG } & \text { Properties of wet gas with vaporized oil } \\ \text { PVTO } & \text { Properties of live oil with dissolved gas }\end{array}$

Oluwasanmi Olabode

Oluwasanmi.olabode@covenantuniversity.edu.ng

1 Department of Petroleum Engineering, Covenant University, Ota, Ogun State, Nigeria

2 Department of Petroleum Engineering, University of Ibadan, Ibadan, Oyo State, Nigeria
SWFN Water saturation function

SOF3 Oil saturation function

\section{Introduction}

The peculiarity of thin oil rim reservoirs irrespective of the depletion strategies used as described by Masoudi (2013) is such that at onset of production high water cuts and gas oil ratios are experienced. This is due to the nature of oil rim reservoirs with gas caps and aquifers larger in volume and size than the oil rim. Although Olabode et al. (2019) had developed a numerical method to predict post water and gas coning, this method is not sufficient enough as it did not incorporate oil rim parameters. Thus, optimizing production and reservoir parameters are key to optimizing oil recovery in oil rim reservoirs. Ibunkun (2011) listed factors affecting productivity of oil rim reservoirs. Olabode (2020) highlighted important parameters that affects oil rim productivity through a sensitivity analysis study. In their study, size of gas cap and aquifer, well placement and length, pay thickness and horizontal well placement are factors that affect oil rim productivity. The effectiveness of horizontal wells over vertical wells in normal reservoirs has been extensively studied

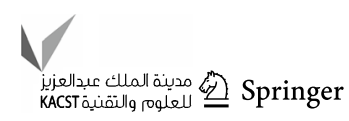


by Olabode and Egeonu (2017) and extensively studied in oil rim reservoirs by Olabode et al. (2018a), Akpabio et al. (2013), Haug et al. (1991) and Kolbikov (2012). In their estimation of oil recovery via improved methods in oil rim reservoirs, Zakirov and Zakirov (1996) proposed four types of oil rims with two approaches to development. The short fall of the background lies in the fact that few parameters used do not fall under the category of important uncertainties as discussed by Olabode (2020). In their summary of the effect of well placement on thin oil rims with bottom and edge water drive, Kabir et al. (2004) analyzed that well placement relative to fluid contact among other less essential factors is essential to optimizing oil recovery. Optimizing horizontal well placement in oil rim reservoirs is essential to oil recovery as noted by Ogiriki et al. (2018), Carpenter (2015) and Keng et al. (2014). Much of their work focused on a single type of oil rim reservoir, use of few important parameters that affect productivity, focus on horizontal well length and neglect of parameters such as height of oil rim, sizes the gas caps and aquifers. Iyare and Marcelle-De silva (2012) considered the effect of well placement based on gas cap and aquifer strength. The authors only considered the strength of the gas caps based on a static variable of the aquifer strength with respect to the fluid contacts.

To maximally optimize production in oil rim reservoirs, important parameters to oil recovery are essential in building the reservoir models. Considering these parameters would dislodge the idea of placing the wells at the fluids contacts but at varying ratios from the fluid contacts. Thus, considering other important factors, proper well placements are essential for reducing water and gas coning, maximizing oil recovery, predicting and forecasting reservoir productivity (Olabode et al. 2018b) and maximizing oil recovery before commencing secondary and enhanced oil recovery (Olabode et al. 2018c).

\section{Methodology}

The grid design is built following the method adopted by Olabode (2020). An experimental method of design (Placket Burman) is used to design 4 oil rim models based on the uncertainties in Table 1. These factors and their values are selected over a wider range of oil rim reservoirs in the Nigerdelta region. The well placement option is omitted from the design analysis but done manually to accommodate for proper allocation of the variable. The black oil option of the
Table 1 Design of experiment variable

\begin{tabular}{llllll}
\hline & Factors & Units & Low & Mid & High \\
& & & -1 & 0 & 1 \\
\hline 1 & Dip & degrees & $1.5^{\circ}$ & 4 & 7 \\
2 & Gas wetness & stb/Mscf & 0.003 & 0.03 & 0.06 \\
3 & Pay thickness & feet & 22 & 42 & 72 \\
4 & Ratio of gas cap to pay thickness & & 0.6 & 3 & 7 \\
5 & Aquifer ratio to pay thickness & & 0.6 & 3 & 7 \\
6 & (Kx, Ky) & mD & 45 & 450 & 4500 \\
7 & Kv/Kh & & 0.004 & 0.04 & 0.4 \\
8 & Wellbore diameter & feet & 0.35 & 0.45 & 0.55 \\
9 & Oil density & lb/cu. ft. & 32 & 40 & 45 \\
10 & HWL & feet & 1100 & 1300 & 1500 \\
11 & Oil rate & stb/day & 1200 & 2200 & 3000 \\
12 & Krw & & 0.25 & 0.35 & 0.55 \\
13 & GOR control & & 3.5 & 5.5 & 7.5 \\
14 & P $_{\text {BH }}$ & psia & 1300 & 1500 & 1800 \\
\hline
\end{tabular}

Table 2 Initialized fluids in place

\begin{tabular}{lll}
\hline Type of reservoir & IOIP (Mstb) & GIIP (Bscf) \\
\hline Oil rim with large gas caps and aquifers & 5732.8 & 320,221 \\
$\begin{array}{l}\text { Oil rims with large gas caps and small } \\
\text { aquifer }\end{array}$ & 29,238 & 345,697 \\
$\begin{array}{l}\text { Oil rims small gas caps and large aqui- } \\
\text { fers and }\end{array}$ & 4892 & 29,212 \\
Oil rims with small gas caps and aquifers & 5920 & 155,384 \\
\hline
\end{tabular}

ECLIPSE software is built with correlations for PVT and solution (as found in figures a, b, c, d and e in "Appendix A") properties which is used to initialize the models to estimate the initial oil in place (IOIP) and initial gas in place (IGIP) (Table 2). The other fluid properties of concern are included in the experimental design analysis. The result from the design in Table 1 forms 18 oil rim models out of which 4 models are selected for horizontal well placement optimization. The selected reservoir models have varying reservoir and operational properties (Table 3) and are summarized as:

1. Oil rim with large gas caps and aquifers.

2. Oil rims with large gas caps and small aquifer.

3. Oil rims small gas caps and large aquifers and

4. Oil rims with small gas caps and aquifers. 


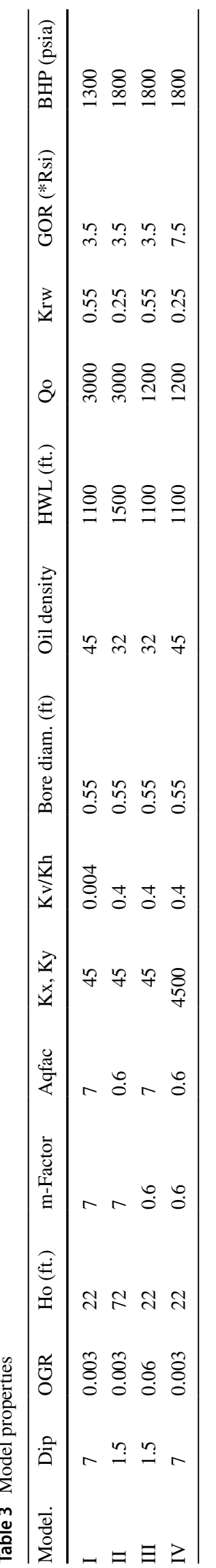

The grid is designed using the full grid plan of the models showing their respective oil saturations are displayed in Figs. 5, 6, 7 and 8 in "Appendix A."

The grid sections are modeled at 20 by 20 by 41 at a Datum depth of $7000 \mathrm{ft}$. with porosity values in Table $12 \mathrm{in}$ "Appendix A" (for Model II). The last 6400 cells are denoted with a porosity value of zero. Other reservoir and dynamic properties used in building the models are found in Tables 1 and 3. A conventional method of selecting well placement relative to fluid contact is done by viewing the section of the models with high oil saturation and varying the placements based on the pay thickness of that particular model and multiplying by some factors. The multiplying factors are $0.25 \mathrm{ft}$., $0.5 \mathrm{ft}$. and $0.75 \mathrm{ft}$. The sizes of each cells in the $\mathrm{z}$ direction of the models depict the pay thickness of the models as described in Table 13 in "Appendix A" (for Model II). The green section of Table 4 is the dimension of the model representing the oil column. Table 14 in "Appendix A" describes the respective fluid contacts for the models which when subtracted amounts to the thickness of the oil column (i.e., WOC minus GOC).

Thus, for an oil rim with a large gas cap and small aquifer;

$@ 0.75 \mathrm{ft}$., placement will be at $0.75 * 72=54 \mathrm{ft}$.

$@ 0.5 \mathrm{ft}$. placement will be at $0.5 * 72=36 \mathrm{ft}$.

$@ 0.25 \mathrm{ft}$. placement will be at $0.25 * 72=18 \mathrm{ft}$.

The grid design is in Cartesian and block centered option; thus, well locations will be in the $x, y$ and $z$ directions. The $k$ direction represents the two options available for completions ( $k$ upper and $\mathrm{k}$ lower). Tables 4, 5, 6 and 7 show selected locations of completions for each of the models based on the above explanation. The models are depleted under a simultaneous production at the onset from two horizontal wells (oil and gas) completed at varying distances from the fluid contacts. The oil production rates for the models range between 1200 and $3000 \mathrm{stb} /$ day with a gas oil ratio constraint range in Table 1 item 13.

Well completions at mid-stream of the pay thickness is introduced in models I and IV.

\section{Results}

The production profiles for each well placements under a model would have been the best to depict trend of fluid productivity, but due to large parameters of gas produced, the production profile is split to be viewed on individual well placement basis. Thus, the focus here will be on oil recovery, gas produced and the water cuts. 
Table 4 Well placement coordinates for Model II

Table 5 Well placement coordinates for Model III

Table 6 Well placement coordinates for Model IV

Table 7 Well placement coordinates for Model I

\begin{tabular}{|c|c|c|c|c|c|c|c|c|c|c|c|}
\hline \multicolumn{12}{|c|}{ Model II } \\
\hline \multicolumn{3}{|c|}{ @ GOC } & \multicolumn{3}{|c|}{$\begin{array}{l}\text { @ } 0.75 \mathrm{ft} \text {. of Ho from } \\
\text { GOC }\end{array}$} & \multicolumn{3}{|c|}{$\begin{array}{l}@ 0.5 \mathrm{ft} \text {. of Ho from } \\
\text { GOC }\end{array}$} & \multicolumn{3}{|c|}{$\begin{array}{l}@ 0.25 \mathrm{ft} \text {. of } \mathrm{Ho} \\
\text { from GOC }\end{array}$} \\
\hline $\mathrm{i}$ & $\mathrm{j}$ & $\mathrm{k}$ & $\mathrm{i}$ & $\mathrm{j}$ & $\mathrm{k}$ & $\mathrm{i}$ & $\mathrm{j}$ & $\mathrm{k}$ & $\mathrm{i}$ & $\mathrm{j}$ & $\mathrm{k}$ \\
\hline 20 & 3 & 8 & 14 & 3 & 9 & 9 & 3 & 10 & 4 & 3 & 12 \\
\hline 20 & 4 & 8 & 14 & 4 & 9 & 9 & 4 & 10 & 4 & 4 & 12 \\
\hline 20 & 5 & 9 & 14 & 5 & 10 & 9 & 5 & 11 & 4 & 5 & 13 \\
\hline 20 & 6 & 9 & 14 & 6 & 10 & 9 & 6 & 11 & 4 & 6 & 13 \\
\hline 20 & 7 & 10 & 14 & 7 & 11 & 9 & 7 & 12 & 4 & 7 & 14 \\
\hline 20 & 8 & 10 & 14 & 8 & 11 & 9 & 8 & 12 & 4 & 8 & 14 \\
\hline
\end{tabular}

\begin{tabular}{|c|c|c|c|c|c|c|c|c|c|c|c|}
\hline \multicolumn{12}{|c|}{ Model III } \\
\hline \multicolumn{3}{|c|}{$\begin{array}{l}\text { @ } 0.75 \mathrm{ft} \text {. of Ho from } \\
\text { WOC }\end{array}$} & \multicolumn{3}{|c|}{ @ $0.5 \mathrm{ft}$. of Ho from WOC } & \multicolumn{3}{|c|}{$\begin{array}{l}\text { @ } 0.25 \mathrm{ft} \text {. of Ho from } \\
\text { WOC }\end{array}$} & \multicolumn{3}{|c|}{ @WOC } \\
\hline $\mathrm{i}$ & $\mathrm{j}$ & $\mathrm{k}$ & $\mathrm{i}$ & $\mathrm{j}$ & $\mathrm{k}$ & $\mathrm{i}$ & $\mathrm{j}$ & $\mathrm{k}$ & $\mathrm{i}$ & $\mathrm{j}$ & $\mathrm{k}$ \\
\hline 12 & 2 & 1 & 10 & 2 & 3 & 7 & 2 & 6 & 2 & 2 & 11 \\
\hline 12 & 3 & 1 & 10 & 3 & 3 & 7 & 3 & 6 & 2 & 3 & 11 \\
\hline 12 & 4 & 2 & 10 & 4 & 4 & 7 & 4 & 7 & 2 & 4 & 12 \\
\hline 12 & 5 & 2 & 10 & 5 & 4 & 7 & 5 & 7 & 2 & 5 & 12 \\
\hline 12 & 6 & 3 & 10 & 6 & 5 & 7 & 6 & 8 & 2 & 6 & 13 \\
\hline 12 & 7 & 3 & 10 & 7 & 5 & 7 & 7 & 8 & 2 & 7 & 13 \\
\hline
\end{tabular}

\begin{tabular}{|c|c|c|c|c|c|c|c|c|c|c|c|c|c|c|}
\hline \multicolumn{15}{|c|}{ Model IV } \\
\hline \multicolumn{3}{|c|}{ @ GOC } & \multicolumn{3}{|c|}{$\begin{array}{l}@ 0.75 \mathrm{ft} \text {. of Ho } \\
\text { from GOC }\end{array}$} & \multicolumn{3}{|c|}{ @ Mid-stream } & \multicolumn{3}{|c|}{$\begin{array}{l}@ 0.75 \mathrm{ft} \text {. of } \mathrm{Ho} \\
\text { from WOC }\end{array}$} & \multicolumn{3}{|c|}{ @ WOC } \\
\hline $\mathrm{i}$ & $\mathrm{j}$ & $\mathrm{k}$ & $\mathrm{i}$ & $\mathrm{j}$ & $\mathrm{k}$ & $\mathrm{i}$ & $\mathrm{j}$ & $\mathrm{k}$ & $\mathrm{i}$ & $\mathrm{j}$ & $\mathrm{k}$ & $\mathrm{i}$ & $\mathrm{j}$ & $\mathrm{k}$ \\
\hline 5 & 3 & 1 & 4 & 4 & 4 & 3 & 8 & 9 & 2 & 3 & 11 & 1 & 11 & 12 \\
\hline 5 & 4 & 1 & 4 & 5 & 4 & 3 & 9 & 9 & 2 & 4 & 11 & 1 & 12 & 12 \\
\hline 5 & 5 & 2 & 4 & 6 & 5 & 3 & 10 & 10 & 2 & 5 & 12 & 1 & 13 & 13 \\
\hline 5 & 6 & 2 & 4 & 7 & 5 & 3 & 11 & 10 & 2 & 6 & 12 & 1 & 14 & 13 \\
\hline 5 & 7 & 3 & 4 & 8 & 6 & 3 & 12 & 11 & 2 & 7 & 13 & 1 & 15 & 14 \\
\hline 5 & 8 & 3 & 4 & 9 & 6 & 3 & 13 & 11 & 2 & 8 & 13 & 1 & 16 & 14 \\
\hline
\end{tabular}

\begin{tabular}{|c|c|c|c|c|c|c|c|c|c|c|c|c|c|c|}
\hline \multicolumn{15}{|c|}{ Model I } \\
\hline \multicolumn{3}{|c|}{ @ GOC } & \multicolumn{3}{|c|}{$\begin{array}{l}@ 0.75 \mathrm{ft} \text {. of } \mathrm{Ho} \\
\text { from } \mathrm{GOC}\end{array}$} & \multicolumn{3}{|c|}{ @ Mid-stream } & \multicolumn{3}{|c|}{$\begin{array}{l}\text { @ } 0.75 \mathrm{ft} . \text { of Ho } \\
\text { from WOC }\end{array}$} & \multicolumn{3}{|c|}{ @ WOC } \\
\hline i & $\mathrm{j}$ & $\mathrm{k}$ & $\mathrm{i}$ & $\mathrm{j}$ & $\mathrm{k}$ & $\mathrm{i}$ & $\mathrm{j}$ & $\mathrm{k}$ & $\mathrm{i}$ & $\mathrm{j}$ & $\mathrm{k}$ & $\mathrm{i}$ & $\mathrm{j}$ & $\mathrm{k}$ \\
\hline 11 & 3 & 1 & 9 & 5 & 3 & 1 & 10 & 14 & 1 & 9 & 18 & 1 & 10 & 22 \\
\hline 11 & 4 & 1 & 9 & 6 & 3 & 1 & 11 & 14 & 1 & 10 & 18 & 1 & 10 & 22 \\
\hline 11 & 5 & 1 & 9 & 7 & 3 & 1 & 12 & 15 & 1 & 11 & 18 & 1 & 10 & 23 \\
\hline 11 & 6 & 1 & 9 & 8 & 3 & 1 & 13 & 15 & 1 & 12 & 18 & 1 & 10 & 23 \\
\hline 11 & 7 & 1 & 9 & 9 & 3 & 1 & 14 & 15 & 1 & 13 & 18 & 1 & 10 & 23 \\
\hline
\end{tabular}




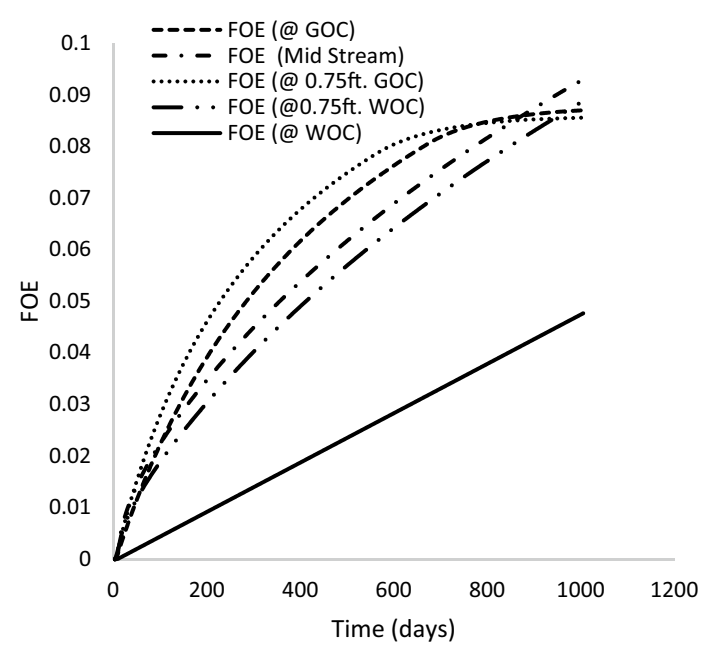

A Oil recovery

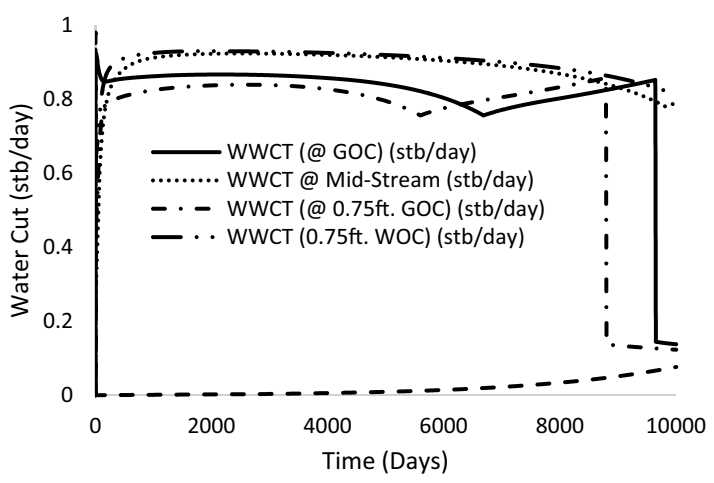

C Well Water Cuts

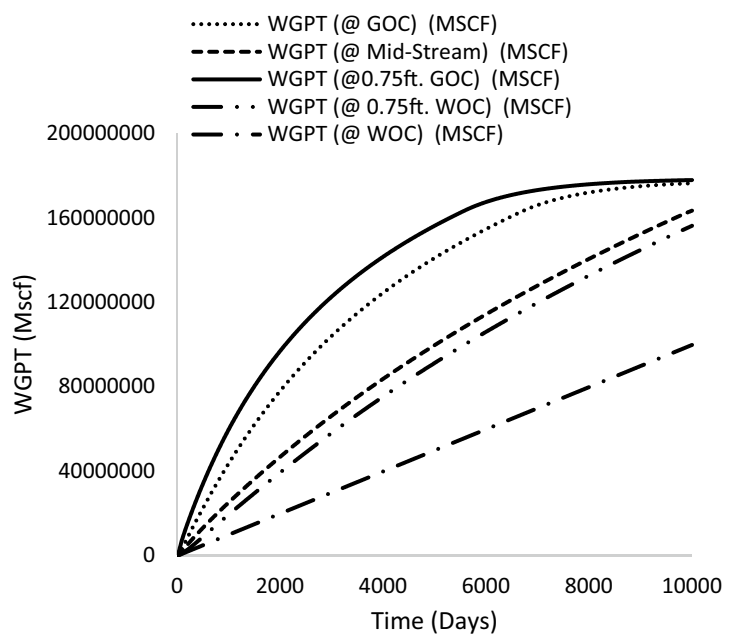

B Gas Production

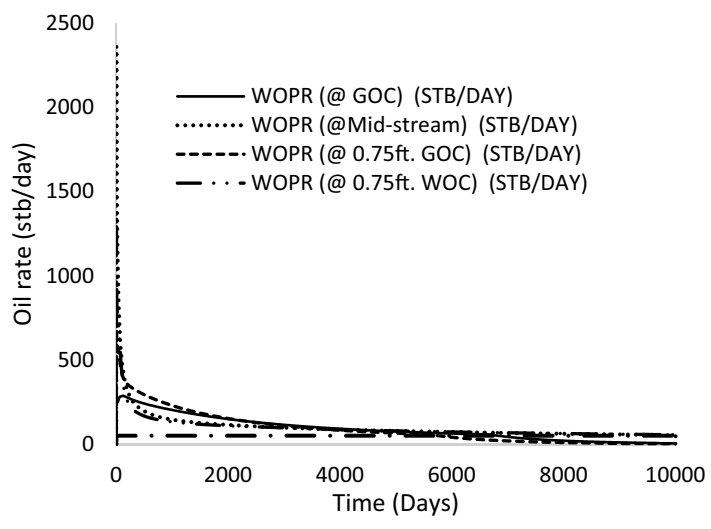

D Well production rates

Fig. 1 a Oil recovery. b Gas production. c Well water cuts. d Well production rates

Table 8 Summary of Model I production

\begin{tabular}{lll}
\hline Well placement & Oil recovery \% & $\begin{array}{l}\text { Gas pro- } \\
\text { duction } \\
\text { (MMSCF) }\end{array}$ \\
\hline @ GOC & 8.7 & 1760 \\
@ WOC & 4.8 & 1640 \\
@ Mid-stream & 9.3 & 1780 \\
@ 0.75ft. GOC & 8.6 & 1570 \\
@ 0.75ft. WOC & 8.9 & 1000 \\
\hline
\end{tabular}

\section{Model I}

The plots in Fig. 1 is that of respective production profiles for model I (large gas cap and aquifer). Figure 1c suggests that for an oil rim with large cap and aquifer, well placement at mid-stream is best for optimum oil recovery at $9.36 \%$. At this oil recovery, gas production is still substantial and produced water cut minimal. Table 8 explains the summary of production from model I. Completing the well at the water oil contact resulted in a low recovery for both oil and gas.

\section{Model II}

Figure $2 \mathrm{a}-\mathrm{d}$ illustrates the production profiles for an oil rim with a larger gas cap compared to the aquifer. The reservoir is dipping at $1.5^{\circ}$ with a pay zone of $65 \mathrm{ft}$. The oil recovery result shows (Fig. 2a) that completing the well at a position of $0.75 \mathrm{ft}$ of the pay zone with respect to the gas oil contact is optimum for oil recovery. The oil recovery rate reduces as the completion is varied close to the gas oil contact. The water cut and rates also follow a similar trend of increases in water cuts as placement is further away from gas oil contact with a faster decline in production rates.

The summary of oil recovery and gas production is displayed in Table 9. 


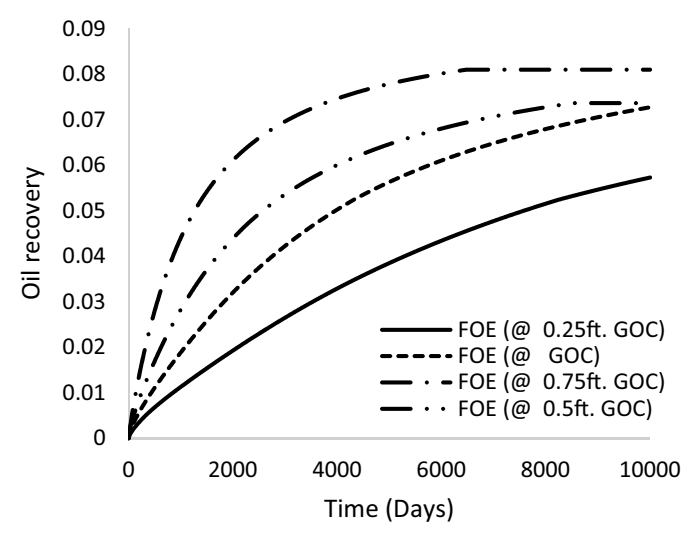

A Oil recovery

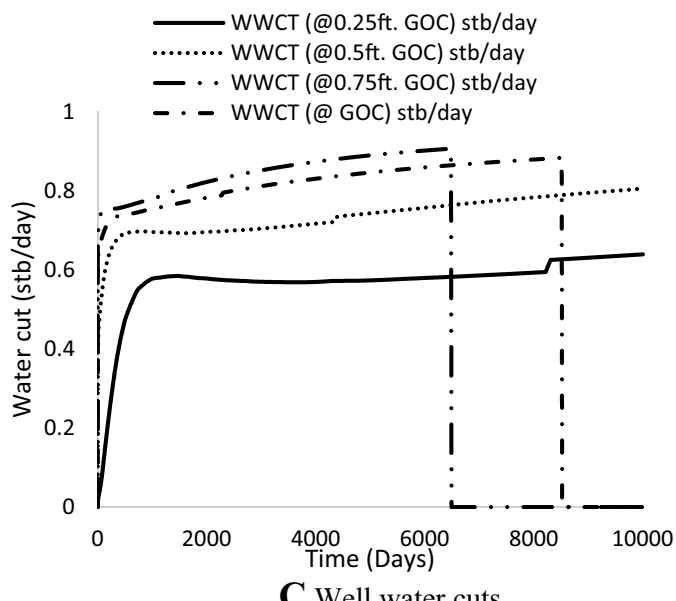

C Well water cuts

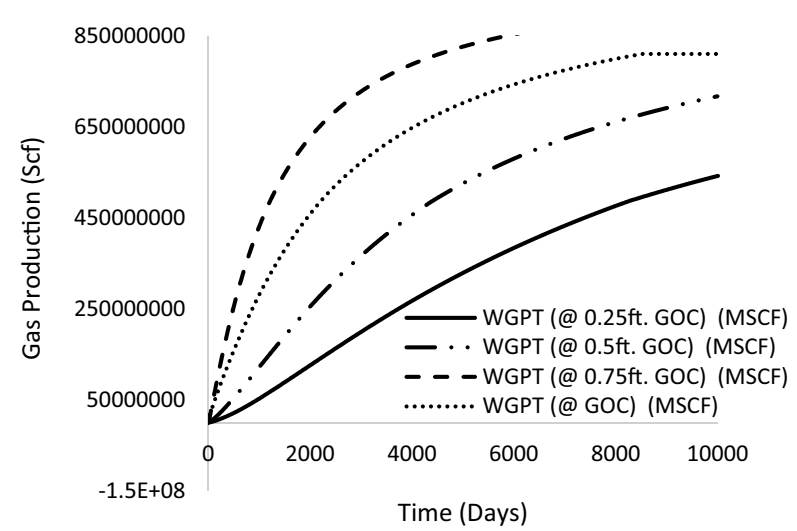

B Gas production

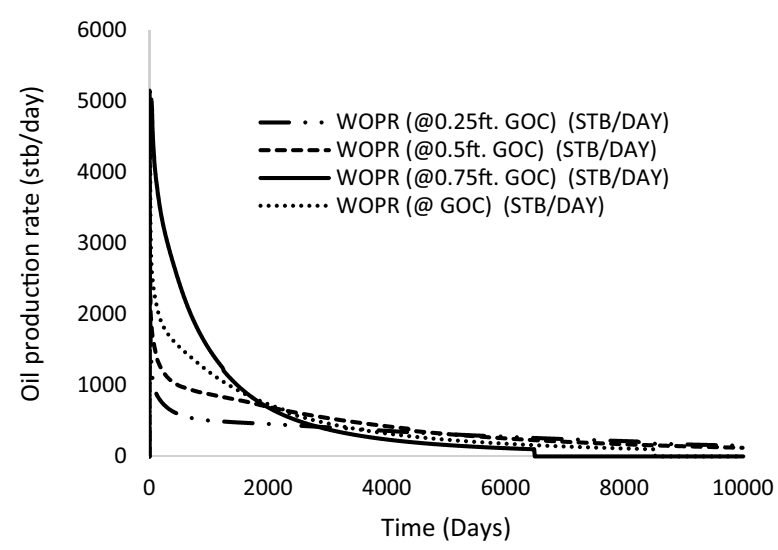

D Well production rates

Fig. 2 a Oil recovery. b Gas production. c Well water cuts. d Well production rates

Table 9 Summary of Model II production

\begin{tabular}{lll}
\hline Well placement & Oil recovery $\%$ & $\begin{array}{l}\text { Gas pro- } \\
\text { duction } \\
\text { (MMSCF) }\end{array}$ \\
\hline @ 0.25ft. GOC & 5.7 & 1640 \\
@ 0.5ft. GOC & 7.3 & 1780 \\
@ 0.75ft. GOC & 8.1 & 1570 \\
@ GOC & 7.4 & 1000 \\
\hline
\end{tabular}

\section{Model III}

The oil rim model has a larger aquifer compared to the gas cap. The pay thickness is $20 \mathrm{ft}$. and is dipping at an angle of $1.5^{\circ}$.
Figures $3 \mathrm{a}-\mathrm{d}$ represents the production profile for this oil rim reservoir. As in the case of model II, placing the wells away from the water oil contact increases the oil recovery (Fig. 3a) and closer to the water oil contact increases water cut as noticed in Fig. 3c. Table 10 illustrates the values of the oil recovery and gas production for Model III.

\section{Model IV}

The model with small gas cap and aquifer has a thickness of $20 \mathrm{ft}$. and also dipping at $1.5^{\circ}$. Due to the nature of the weak drives (gas cap and aquifer), the oil recovery results are low (Table 11, Fig. 4a) when compared with other models. For this case scenario, the order of oil recovery is completion closer to GOC is greater than completion at mid-stream and is greater than completion closer to the WOC. There is an 


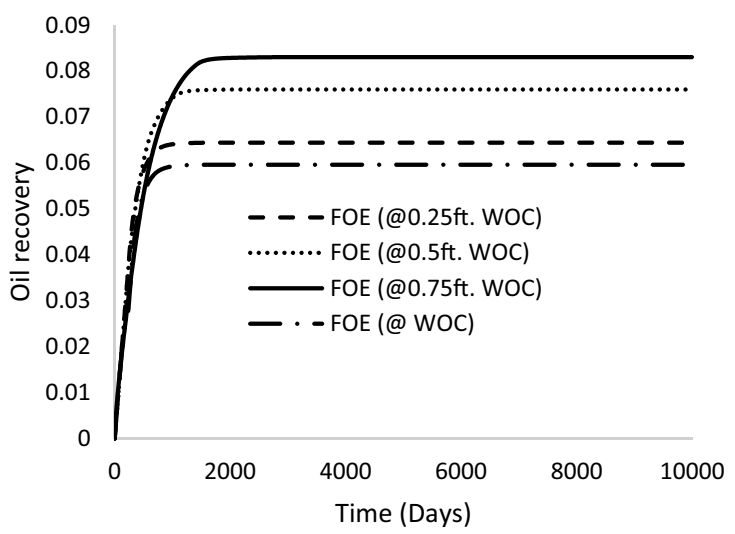

A Oil recovery profile

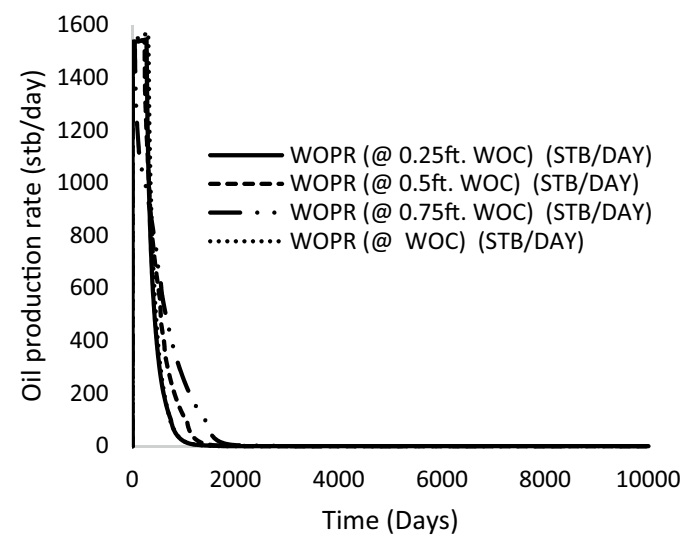

C Oil production rate profile

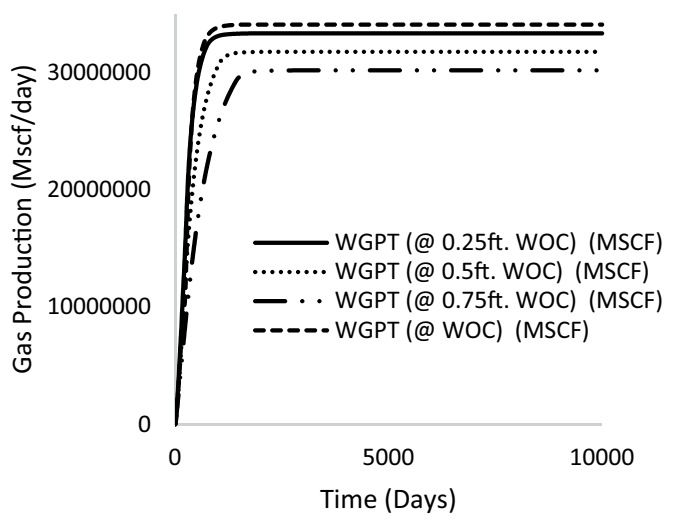

B Gas Production.

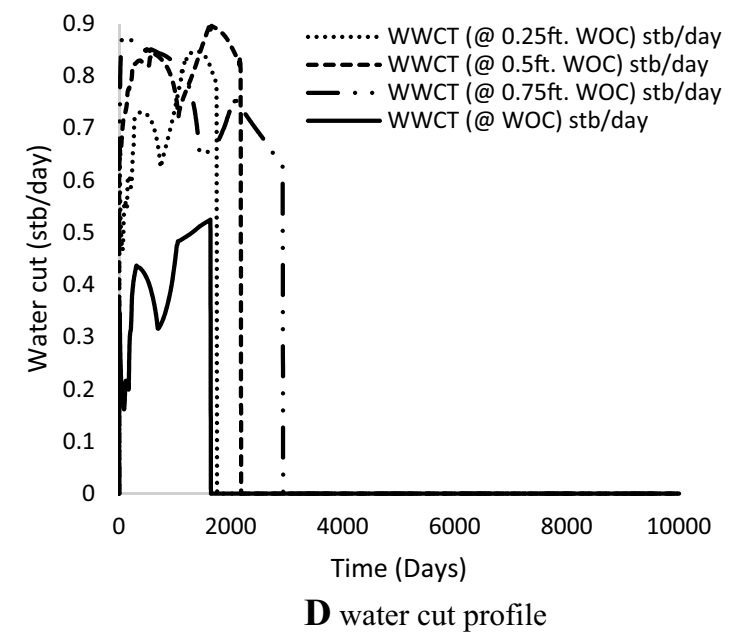

Fig. 3 a Oil recovery profile. b Gas production. c Oil production rate profile. d Water cut profile

Table 10 Summary of Model III production

\begin{tabular}{lll}
\hline Well placement & Oil recovery $\%$ & $\begin{array}{l}\text { Gas pro- } \\
\text { duction } \\
\text { (MMSCF) }\end{array}$ \\
\hline @ 0.25ft. WOC & 8.30 & 33,341 \\
@ 0.5ft. WOC & 7.60 & 31,775 \\
@ 0.75ft. WOC & 6.44 & 30,193 \\
@ WOC & 5.96 & 34,095 \\
\hline
\end{tabular}

Table 11 Summary of model IV production

\begin{tabular}{lll}
\hline Well placement & Oil recovery $\%$ & $\begin{array}{l}\text { Gas pro- } \\
\text { duction } \\
\text { (MMSCF) }\end{array}$ \\
\hline @ GOC & 2.56 & 1760 \\
@ WOC & 3.99 & 1640 \\
@ Mid-stream & 5.33 & 1780 \\
@ 0.75ft. GOC & 5.23 & 1570 \\
@ 0.75ft. WOC & 5.96 & 1000 \\
\hline
\end{tabular}

appreciable gas production that has not hindered oil production while the model recorded an average production rate and water cuts (Fig. 4b-d).

\section{Conclusion and recommendation}

For optimum recovery of oil and gas from oil rim reservoirs, placements of horizontal wells must be done based on the sizes or strengths of the reservoir drive mechanisms, in this case basically the gas cap and aquifer. Under a concurrent production of oil and gas, this procedure is essential to prevent the production of gas jeopardizing that of oil and vice versa. Varying the horizontal well placement with respect to the fluid contacts for oil rims under this production scenario helps to determine the optimum well placement to effectively produce gas and oil. The production and subsequent sales of gas ensure project viability and improve the net present value. Optimizing production parameters such as well placement is essential for optimizing oil recovery 


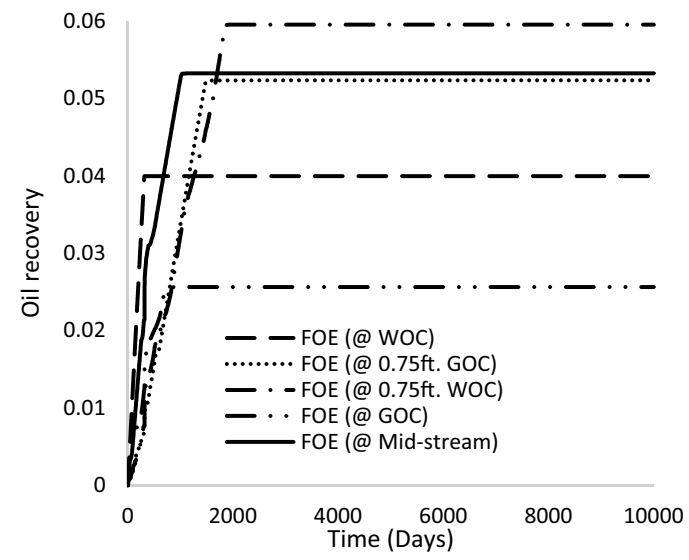

A Oil recovery profile

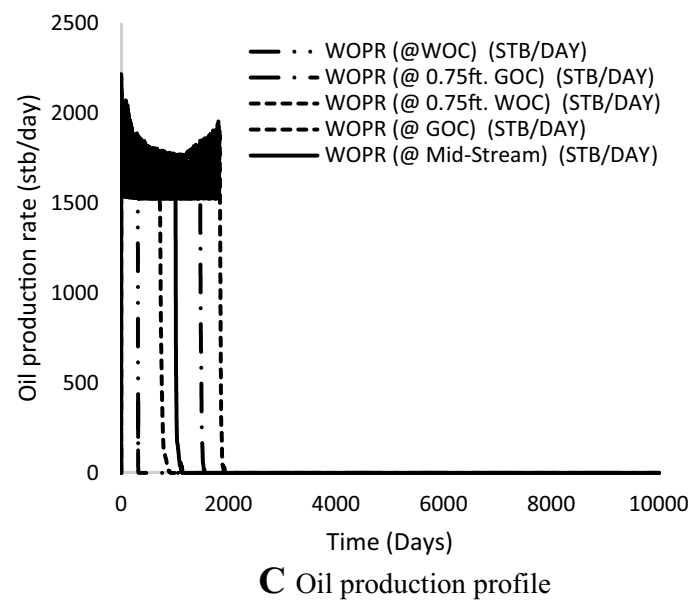

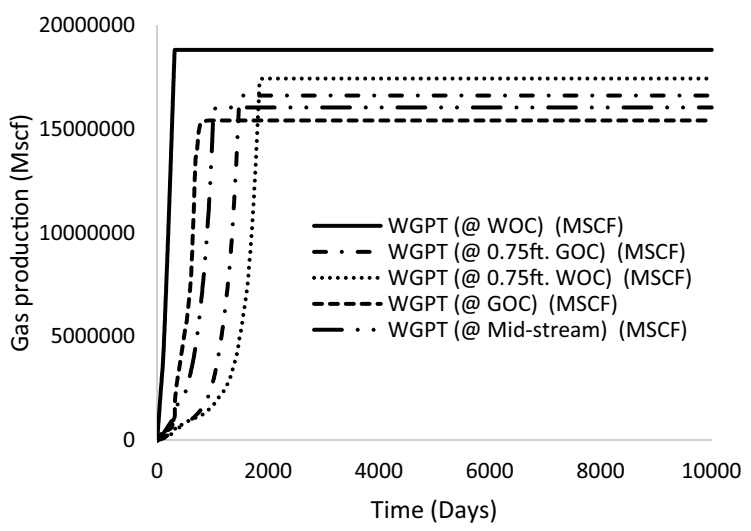

B Gas Production.

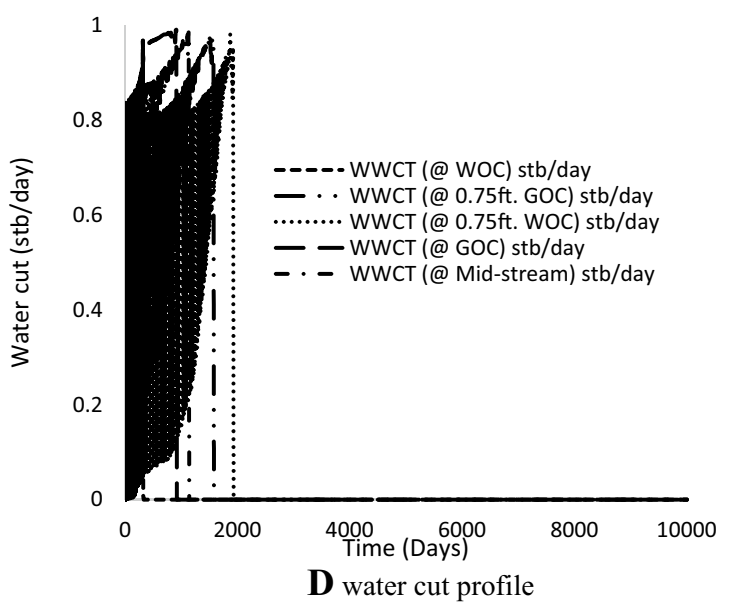

Fig. 4 a Oil recovery profile. b Gas production. c Oil production profile. d Water cut profile

in ultra-thin oil rim reservoirs before the implementation of secondary and enhanced oil recovery as described by Olabode et al. (2018c). Enhanced oil recovery methods introduced by Olabode et al. (2020a) and Olabode et al. (2020b) for heavy oil reservoirs can also be considered for heavymedium oil rim reservoirs. These models can be used as a matrix for similar field case studies.

The authors have fully followed the code and ethics in the development of this manuscripts as it relates to sources and usage of data and abiding to publishing principles. Also, there exists no conflict of interests in the development of this research.

Funding Open access funding to be provided by the author's affiliation : Covenant University, sango Ota, ogun state, Nigeria.
Open Access This article is licensed under a Creative Commons Attribution 4.0 International License, which permits use, sharing, adaptation, distribution and reproduction in any medium or format, as long as you give appropriate credit to the original author(s) and the source, provide a link to the Creative Commons licence, and indicate if changes were made. The images or other third party material in this article are included in the article's Creative Commons licence, unless indicated otherwise in a credit line to the material. If material is not included in the article's Creative Commons licence and your intended use is not permitted by statutory regulation or exceeds the permitted use, you will need to obtain permission directly from the copyright holder. To view a copy of this licence, visit http://creativecommons.org/licenses/by/4.0/.

\section{Appendix A}

See Figs. 5, 6, 7 and 8 . 


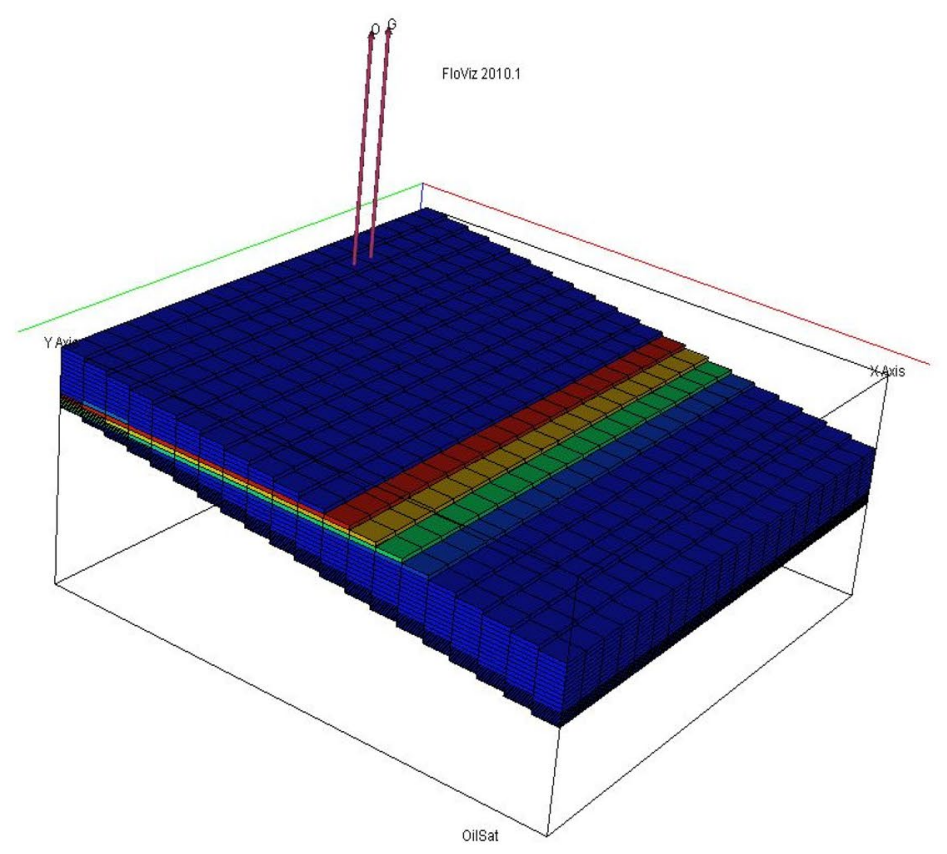

0.00000

Fig. 5 Grid view of Model I

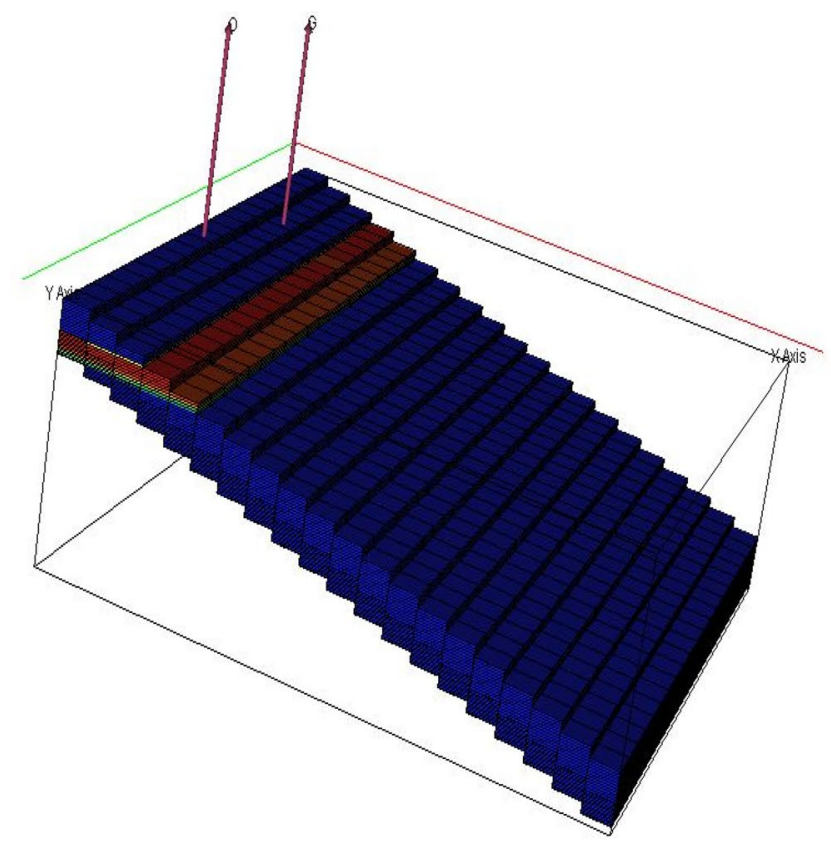

oilsat

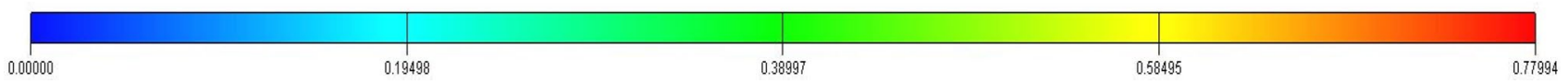

Fig. 6 Grid view of Model III 


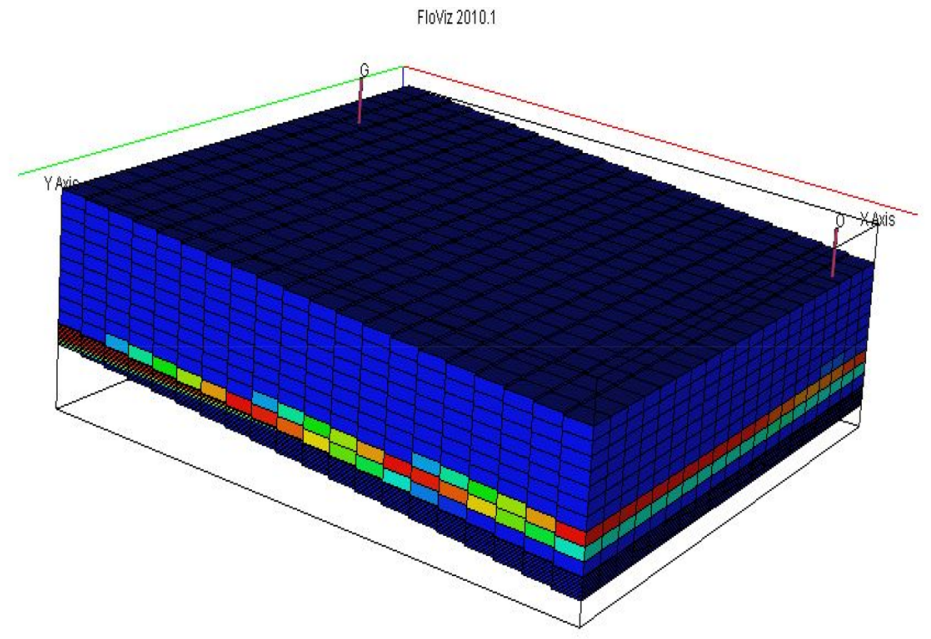

Oilsat

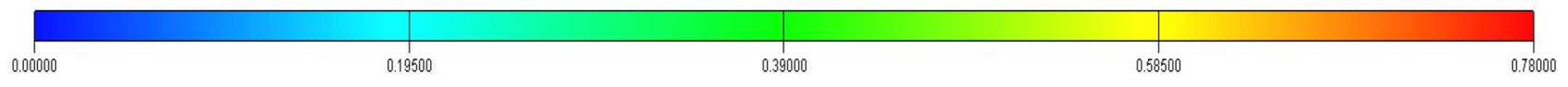

Fig. 7 Grid view of Model II

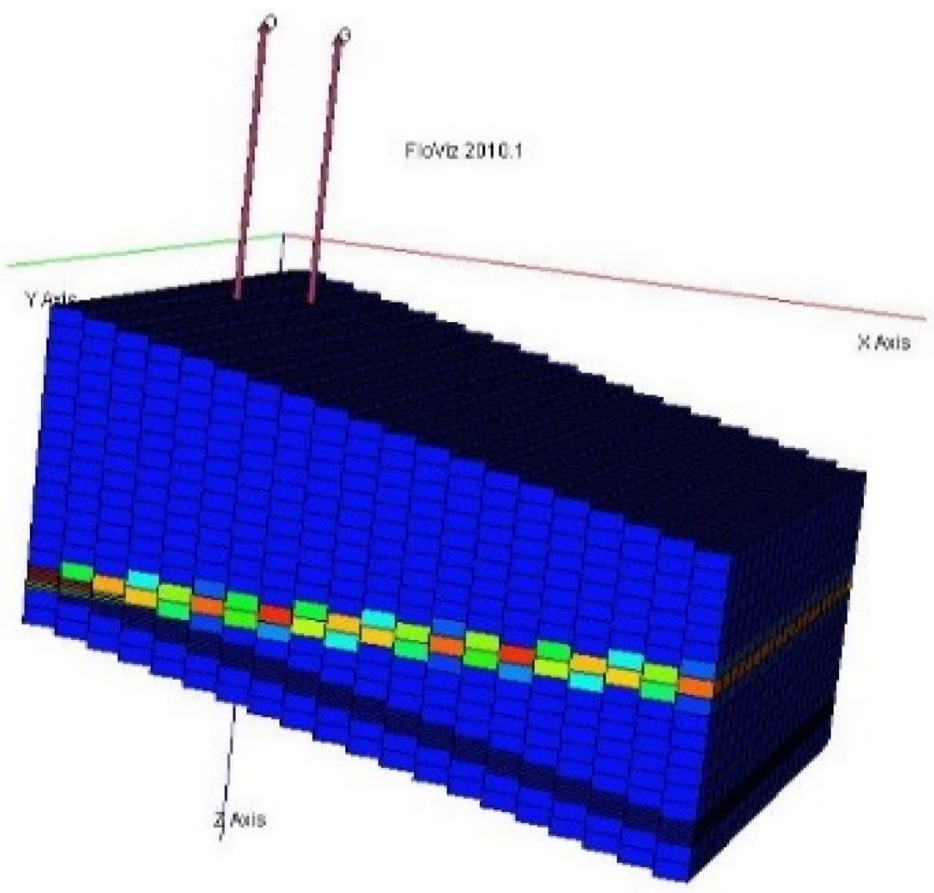

oisat

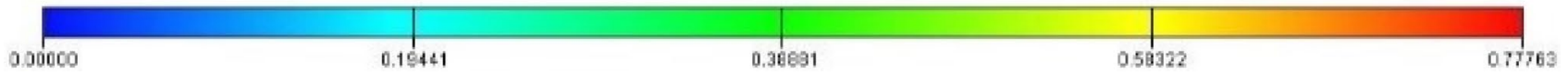

Fig. 8 Grid view of Model IV

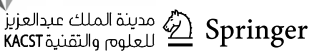




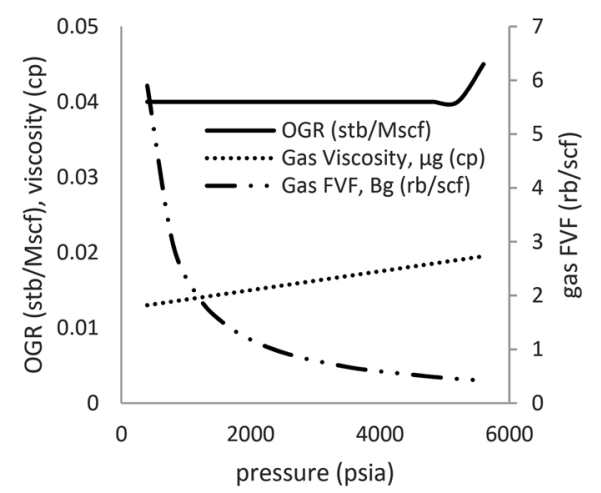

(a) PVTG

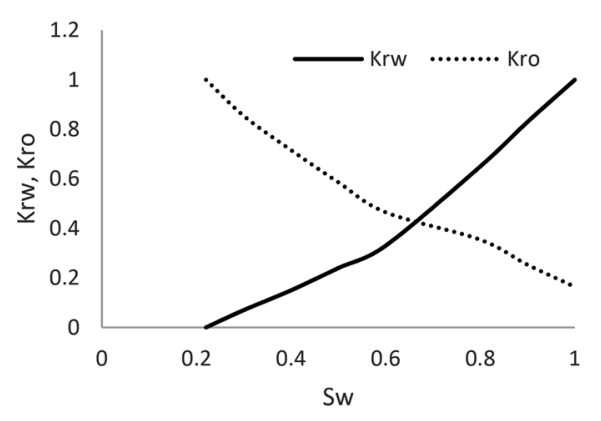

(c) SWFN

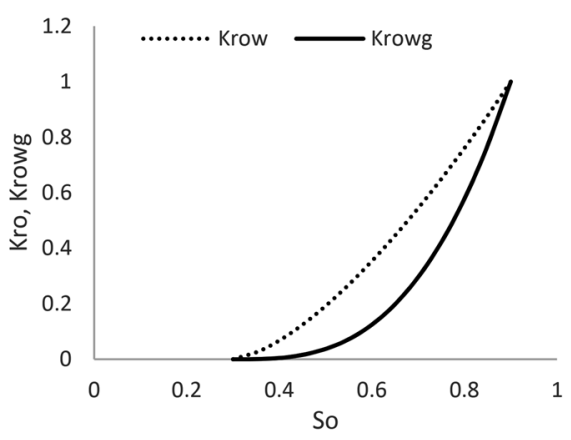

(e) $\mathrm{SOF} 3$

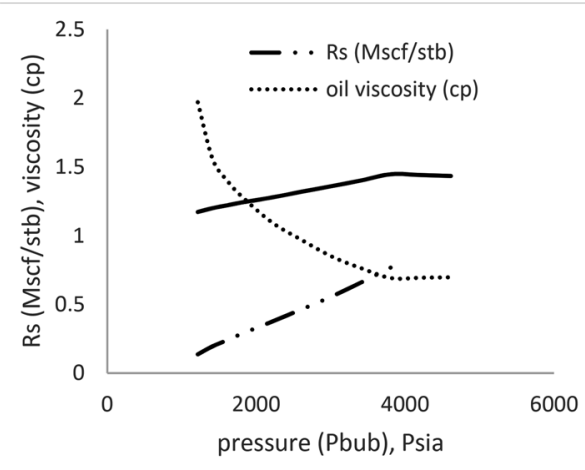

(b) PVTO

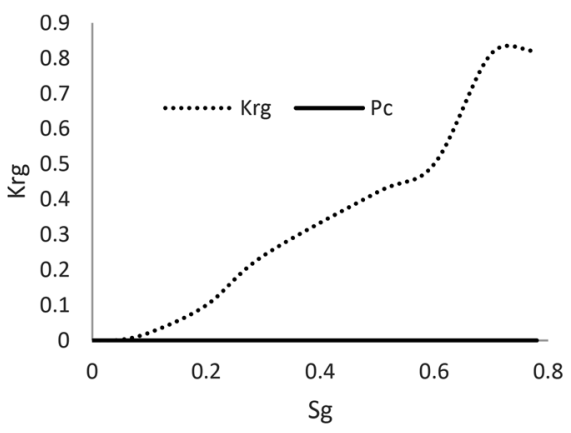

(d) SGFN

See Tables 12, 13 and 14.

Table 12 Porosity values (Model II)

\begin{tabular}{|c|c|c|c|c|c|c|c|c|c|}
\hline $400 * 0.29$ & $400 * 0.24$ & $400 * 0.27$ & $400 * 0.26$ & $400 * 0.28$ & $400 * 0.25$ & $400 * 0.26$ & $400 * 0.28$ & $400 * 0.26$ & $400 * 0.28$ \\
\hline $400 * 0.29$ & $400 * 0.24$ & $400 * 0.25$ & $400 * 0.24$ & $400 * 0.27$ & $400 * 0.28$ & $400 * 0.29$ & $400 * 0.28$ & $400 * 0.29$ & $400 * 0.24$ \\
\hline $400 * 0.26$ & $400 * 0.27$ & $400 * 0.27$ & $400 * 0.24$ & $400 * 0.26$ & $6400 * 0.00$ & & & & \\
\hline
\end{tabular}

Table 13 Fluid contact locations

\begin{tabular}{lll}
\hline Models & GOC & WOC \\
\hline I & 7440 & 7420 \\
II & 7795 & 7767 \\
III & 7144 & 7214 \\
IV & 7106 & 7086 \\
\hline
\end{tabular}


Table 14 Tops data for Model II

\begin{tabular}{|c|c|c|c|c|c|c|c|}
\hline \multirow{2}{*}{$\begin{array}{l}\mathrm{DX} \\
\mathrm{DY} \\
\mathrm{DZ}\end{array}$} & \multirow{2}{*}{$\begin{array}{l}300 \\
300 \\
46\end{array}$} & \multicolumn{2}{|c|}{$\mathrm{X}$-direction } & \multicolumn{2}{|c|}{ Y-direction } & \multicolumn{2}{|c|}{ Z-direction } \\
\hline & & 1 & 20 & 1 & 20 & 1 & 1 \\
\hline $\mathrm{DZ}$ & 46 & 1 & 20 & 1 & 20 & 2 & 2 \\
\hline $\mathrm{DZ}$ & 46 & 1 & 20 & 1 & 20 & 3 & 3 \\
\hline DZ & 46 & 1 & 20 & 1 & 20 & 4 & 4 \\
\hline $\mathrm{DZ}$ & 46 & 1 & 20 & 1 & 20 & 5 & 5 \\
\hline $\mathrm{DZ}$ & 46 & 1 & 20 & 1 & 20 & 6 & 6 \\
\hline $\mathrm{DZ}$ & 46 & 1 & 20 & 1 & 20 & 7 & 7 \\
\hline $\mathrm{DZ}$ & 46 & 1 & 20 & 1 & 20 & 8 & 8 \\
\hline $\mathrm{DZ}$ & 46 & 1 & 20 & 1 & 20 & 9 & 9 \\
\hline $\mathrm{DZ}$ & 46 & 1 & 20 & 1 & 20 & 10 & 10 \\
\hline $\mathrm{DZ}$ & 46 & 1 & 20 & 1 & 20 & 11 & 11 \\
\hline $\mathrm{DZ}$ & 46 & 1 & 20 & 1 & 20 & 12 & 12 \\
\hline $\mathrm{DZ}$ & 46 & 1 & 20 & 1 & 20 & 13 & 13 \\
\hline $\mathrm{DZ}$ & 46 & 1 & 20 & 1 & 20 & 14 & 14 \\
\hline $\mathrm{DZ}$ & 46 & 1 & 20 & 1 & 20 & 15 & 15 \\
\hline $\mathrm{DZ}$ & 5 & 1 & 20 & 1 & 20 & 16 & 16 \\
\hline $\mathrm{DZ}$ & 8 & 1 & 20 & 1 & 20 & 17 & 17 \\
\hline $\mathrm{DZ}$ & 8 & 1 & 20 & 1 & 20 & 18 & 18 \\
\hline $\mathrm{DZ}$ & 8 & 1 & 20 & 1 & 20 & 19 & 19 \\
\hline $\mathrm{DZ}$ & 8 & 1 & 20 & 1 & 20 & 20 & 20 \\
\hline $\mathrm{DZ}$ & 8 & 1 & 20 & 1 & 20 & 21 & 21 \\
\hline $\mathrm{DZ}$ & 8 & 1 & 20 & 1 & 20 & 22 & 22 \\
\hline $\mathrm{DZ}$ & 8 & 1 & 20 & 1 & 20 & 23 & 23 \\
\hline DZ & 8 & 1 & 20 & 1 & 20 & 24 & 24 \\
\hline $\mathrm{DZ}$ & 8 & 1 & 20 & 1 & 20 & 25 & 25 \\
\hline $\mathrm{DZ}$ & 46 & 1 & 20 & 1 & 20 & 26 & 26 \\
\hline $\mathrm{DZ}$ & 46 & 1 & 20 & 1 & 20 & 27 & 27 \\
\hline DZ & 46 & 1 & 20 & 1 & 20 & 28 & 28 \\
\hline $\mathrm{DZ}$ & 46 & 1 & 20 & 1 & 20 & 29 & 29 \\
\hline $\mathrm{DZ}$ & 46 & 1 & 20 & 1 & 20 & 30 & 30 \\
\hline $\mathrm{DZ}$ & 46 & 1 & 20 & 1 & 20 & 31 & 31 \\
\hline DZ & 46 & 1 & 20 & 1 & 20 & 32 & 32 \\
\hline DZ & 46 & 1 & 20 & 1 & 20 & 33 & 33 \\
\hline DZ & 46 & 1 & 20 & 1 & 20 & 34 & 34 \\
\hline $\mathrm{DZ}$ & 46 & 1 & 20 & 1 & 20 & 35 & 35 \\
\hline $\mathrm{DZ}$ & 46 & 1 & 20 & 1 & 20 & 36 & 36 \\
\hline $\mathrm{DZ}$ & 46 & 1 & 20 & 1 & 20 & 37 & 37 \\
\hline DZ & 46 & 1 & 20 & 1 & 20 & 38 & 38 \\
\hline DZ & 46 & 1 & 20 & 1 & 20 & 39 & 39 \\
\hline DZ & 46 & 1 & 20 & 1 & 20 & 40 & 40 \\
\hline DZ & 5 & 1 & 20 & 1 & 20 & 41 & 41 \\
\hline
\end{tabular}

\section{References}

Akpabio J, Akpanika OI, Isemin A (2013) Horizontal well performance in thin oil rim reservoirs. Int J Eng Sci Res Technol 2(2). ISSN:2277-9655

Carpenter C (2015) Smart horizontal well development of thin oil rim reservoirs. J Pet Technol 67(11)
Haug BT, Ferguson WI, Kydland T, Norsk Hydro AS (1991) Horizontal wells in the water zone: the most effective way of tapping oil from thin oil zones? In: 66th Annual technical conference and exhibition of the society of petroleum engineers held in Dallas, TX, October 6-9. SPE 22929

Ibunkun S (2011) Evaluation of oil rim reservoirs development-a case study. Master of Science Thesis at the Department of Petroleum Engineering, University of Ibadan 
Iyare U, Marcelle-De silva J (2012) Effect of gas cap and aquifer strenght on the optimal well location for thin oil rim reservoirs. SPETT 2012 Energy Conference and Exhibition. Port of Spain, Trinidad

Kabir CS, Agamini M, Holguin RA (2004) Production strategy for thin oil columns in saturated reservoirs. Spe annual technical conference, Abuja

Keng SC, Masoudi R, Kartooti H, Shaedin R, Othman MB, Petronas, (2014) Smarthorizontal well drilling and completion for effective developmentof thin oil rim reservoirs in Malasia. International petroleum technology conference, Kuala Lumpur, December $10-12$

Kolbikov S (2012) Peculiarities of thin oil rim development paper SPE 160678 presented at the SPE Russian oil and gas exploration and production technical conference and exhibition, 16 Moscow, Russia

Masoudi R (2013) How to get the most out of your oil rim reservoirs? Reservoir management and hydrocarbon recovery enhancement initiatives, SPE-16740-MS

Ogiriki SO, Imonike GO, Ogolo NO, Onyekonwu MO (2018) Optimum well type for oil rim reservoirs with large gas cap and strong aquifer. In: SPE-193411-MS, annual international conference of the SPE August 6-8, Lagos, Nigeria

Olabode O (2020) Effect of water and gas injection schemes on synthetic oil rim models. J Pet Explor Prod Technol. https://doi. org/10.1007/s13202-020-00850-3

Olabode OA, Egeonu GI (2017) Effect of horizontal well length variation on productivity of gas condensate well. Int J Appl Eng Res 12(20):9271-9284
Olabode O, Egeonu G, Ojo T, Oguntade T, Bamigboye O (2018a) Production forecast for Niger delta oil rim synthetic reservoirs on performance of thin oil rim reservoirs. Data in Brief, Open access

Olabode OA, Orodu OD, Isehunwa S, Mamudu A, Rotimi T (2018b) Effect of foam and WAG (water alternating gas) injection. J Petrol Sci Eng 171:1443-1454

Olabode O, Egeonu G, Ojo T, Oguntade T, Bamigboye O (2018c) Predicting the effect of well trajectory and production rates on concurrent oil and gas recovery from thin oil rims. IOP Conf Ser Mater Sci Eng 413:012051

Olabode O, Etim E, Emeka O, Tope O, Victoria A, Charles O (2019) Predicting post breakthrough performance of water and gas coning. Int J Mech Eng Technol 10(2):255-272

Olabode O, Alaigba D, Oramabo D, Bamigboye O (2020a) Modelling low salinity water flooding as a tertiary oil recovery technique. J Model Simul Eng. https://doi.org/10.1155/2019/6485826

Olabode O, Ojo T, Oguntade T, Oduwole D (2020b) Recovery potential of biopolymer (B-P) formulation from solanum tuberosum (waste) starch for enhancing recovery from oil reservoirs. Energy Reports. 6:1448-1455

Zakirov SN, Zakirov IS (1996) New methods for improved oil recovery of thin oil rims. In: SPE European petroleum conference, Milan, Italy, 22-24 October, SPE 36845

Publisher's Note Springer Nature remains neutral with regard to jurisdictional claims in published maps and institutional affiliations. 